\title{
Lichinodium is a new lichenized lineage in the Leotiomycetes
}

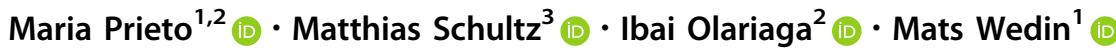

Received: 17 July 2018 / Accepted: 26 November 2018/Published online: 13 December 2018

(C) The Author(s) 2018

\begin{abstract}
Here, we show that Lichinodium (Lichinaceae, Lichinomycetes, Ascomycota) constitutes a formerly unrecognized lineage within the Leotiomycetes, thus being the first lichenized lineage recognized in the superclass Sordariomyceta (Leotiomycetes, Laboulbeniomycetes and Sordariomycetes). To infer the position of Lichinodium, we constructed two multilocus phylogenies based on six and five gene regions (nuLSU rDNA, nuSSU rDNA, mtSSU rDNA, RPB1, RPB2 and MCM7) including main Pezizomycotina groups in the first analysis and focusing secondly on a comprehensive selection of Sordariomyceta. The results show that Lichinodium is sister to Leotiaceae. We discuss the morphological and ecological similarities between Lichinodium and other Leotiomycetes, and describe the new order Lichinodiales and family Lichinodiaceae. The sister relationship between Sordariomycetes and Laboulbeniomycetes is here supported as it is the relationship between this clade and the Leotiomycetes. The results also support the polyphyly of Helotiales, the recognition of the Leotiales in a strict sense or the inclusion of the Triblidiales in Leotiomycetes. The photobionts of Lichinodium were sequenced for two genetic markers (rbcLX and 16S rDNA) and identified as Rhizonema, a recently described genus of filamentous cyanobacteria belonging to Nostocaceae. TEM studies revealed that the mycobiont-cyanobiont interface in Lichinodium does not produce haustoria, thus differing from a typical Lichinomycete (e.g. Ephebe).
\end{abstract}

Keywords Discomycetes · Haustoria · Lichenized fungi - Lichinomycetes · Lichinodiaceae $\cdot$ Lichinodiales · Pezizomycotina

\section{Introduction}

Lichenization, the symbiotic process in which fungi utilize green algal or cyanobacterial photobionts for the provision of carbohydrates, is a very common and successful lifestyle among Ascomycota, where currently more than 19,000 lichenized species (27\% of the known Ascomycota) are

Electronic supplementary material The online version of this article (https://doi.org/10.1007/s13225-018-0417-5) contains supplementary material, which is available to authorized users.

Maria Prieto

maria.prieto@nrm.se

1 Department of Botany, Swedish Museum of Natural History, PO Box 50007, 10405 Stockholm, Sweden

2 Departamento de Biología y Geología, Física y Química Inorgánica, Universidad Rey Juan Carlos, C/Tulipán s/n, 28933 Móstoles, Madrid, Spain

3 Herbarium Hamburgense, Institute for Plant Science and Microbiology, University of Hamburg, Ohnhorststr. 18, 22609 Hamburg, Germany accepted (Lücking et al. 2016). Lichenized fungi are typically characterized by a specialized three-dimensional structure-the lichen thallus-within which the fungus houses the photobionts. However, the variation in the type and range of symbiosis between fungi, algae and cyanobacteria make the definition of the concept "lichen" difficult (Hawksworth 1988; Grube and Hawksworth 2007). That is particularly true in filamentous lichens, which in contrast to the main lichen groups do not develop stratified thalli. Instead the shape of the association is determined by the algal filaments, which are either surrounded by a thin layer of fungal hyphae (e.g. Calotrichopsis, Cystocoleus, Lichinodium, Racodium, Thermutis) or contain the fungal hyphae inside (e.g. Ephebe, Spilonema, Zahlbrucknerella) (Henssen 1963, 1977; Ozenda and Clauzade 1970).

Extant lichenized fungi occur in seven classes of Pezizomycotina: Arthoniomycetes, Candelariomycetes, Coniocybomycetes, Dothideomycetes, Eurotiomycetes, Lecanoromycetes and Lichinomycetes. The remaining classes (Geoglossomycetes, Laboulbeniomycetes, Leotiomycetes, Orbiliomycetes, Pezizomycetes, 
Sordariomycetes and Xylonomycetes) are exclusively composed of non-lichenized members (Lumbsch and Huhndorf 2010; Jaklitsch et al. 2016). There are very few filamentous lichens, but they appear in several classes of Ascomycota, and represent fungi associated with a number of different photobionts. They can be found in the Lecanoromycetes (e.g. Polychidium and Spilonema with cyanobacteria in Peltigerales and Coenogonium with Trentepohlia in Ostropales), in Dothideomycetes (Cystocoleus and Racodium with Trentepohlia in Capnodiales), in Eurotiomycetes (Pyrenothrix in Chaetothyriales with Scytonema) and in the Lichinomycetes (e.g. Ephebe with Stigonema, Thermutis and Zahlbrucknerella with Scytonema (Henssen 1963; Herrera-Campos et al. 2005; Muggia et al. 2008; Hawksworth et al. 2011). Although two more filamentous species associated with Trentepohlia have been described, their phylogenetic and taxonomic position is not clear (i.e. Physolinum monile, Davis et al. 1989 and $R a-$ coleus, the latter suggested as "? Capnodiales (incertae sedis)" in Hawksworth et al. 2011).

Within the Pezizomycotina, the Lichinomycetes is sister to the Coniocybomycetes (Prieto et al. 2013) and together they constitute a lineage distantly related to the main lineage including most lichenized groups. Lichinomycetes diversified around 175 Mya (Prieto and Wedin 2013) and comprises ca. 350 species distributed worldwide, being probably one of the least understood lichen-forming fungal groups. They have cyanobacteria as photobionts (Schultz et al. 2001), which allow these fungi to benefit from nitrogen fixation (Crittenden et al. 2007). The diversity of growth forms, ascoma types and development, anatomy, and cyanobionts is substantial within the group. However, the natural relationships and character evolution within this group are still very poorly understood. As part of an ongoing phylogenetic work on Lichinomycetes we discovered that the genus Lichinodium did not belong there as current classifications suggest (Jaklitsch et al. 2016; Lücking et al. 2016) based on the anatomical studies of Henssen (1963). Lichinodium comprises four filamentous lichen species (Henssen 1974), which form tiny cushions of branched filaments (Fig. 1) composed of threads of cyanobionts surrounded by hyphal cells forming a collar (Fig. 2). They develop gelatinous brownish apothecia with indistinct proper and thalline margin (Figs. 1, 3), and asexual conidiomata which are known at least for two of the species (Fig. 3). Species of Lichinodium grow on conifer twigs, tree trunks or rocks, sometimes overgrowing other lichens or mosses. In general, the species exhibit a pronounced preference for cool, humid environments.

The photobionts of Lichinodium consist of filaments that are often split and twisted, and enclosed by a relatively thick hyphal collar (Fig. 2; Henssen 1974). These photobionts have been identified as the filamentous, cyanobacterial genus Scytonema (Henssen 1963; Schultz and Büdel 2002) based on morphology alone. However, photobionts may show a different morphology in the lichenized state, in free-living samples or in cultured strains (Schultz and Büdel 2002). Moreover, it has been recently demonstrated (Lücking et al. 2009) that the photobionts of several tropical cyanolichens, supposed to represent Scytonema, belong instead to a novel, previously unrecognized lineage. All this indicates the need for a molecular identification approach of the Lichinodium photobionts.

The aim of this study is to investigate the phylogenetic relationships of Lichinodium within the Pezizomycotina, to compare Lichinodium morphologically and anatomically with its closest phylogenetic relatives, and to study the identity of the cyanobiont partners.

\section{Materials and methods}

\section{Taxon sampling}

Six specimens of Lichinodium belonging to two of the four species of the genus were used for the analyses (Electronic Supplementary Material). Two analyses were performed. The first investigated the overall relationships of Lichinodium, based on a matrix including a wide representation of main groups of Pezizomycotina and including six genes (nuLSU rDNA, nuSSU rDNA, mtSSU rDNA, RPB1, RPB2 and MCM7; Electronic Supplementary Material). For the second analysis and based on the first analysis, a matrix including a larger sampling of the groups closely related to Lichinodium was compiled. The latter includes a larger sampling of Leotiomycetes, Laboulbeniomycetes and Sordariomycetes, and it is based on five gene regions (nuLSU, nuSSU, mtSSU, RPB1 and RPB2; Electronic Supplementary Material). A third analysis included the cyanobiont sequences and their closest relatives.

\section{Molecular techniques}

DNA was extracted using DNeasy Plant Mini Kit (Qiagen) according to the manufacturer's instructions. We amplified nuLSU region with LR0R (Rehner and Samuels 1994), LR3R, LR5 and LR7 (Vilgalys and Hester 1990) primers in different combinations. The nuSSU was amplified using NS1 (White et al. 1990), NS21, nuSSU-1203-3' (NS23 reverse) and NSU24 (Gargas and Taylor 1992). The mtSSU region was amplified with mtSSU1 and mtSSU3R (Zoller et al. 1999). We used the primers MCM7-709for and MCM7-1348rev (Schmitt et al. 2009) for amplification of the MCM7 region and in some cases we carried out a nested PCR using $1 \mu \mathrm{l}$ of the PCR product and the internal 
Fig. 1 a, b Lichinodium

ahlneri, growth habit and ascomata. a Thallus with three mature apothecia lacking a proper margin. b Thallus with one, slightly convex apothecium (right) and two juvenile apothecia (left), another juvenile apothecium in small rosette at the bottom. $\mathbf{c}, \mathbf{d} L$. sirosiphoideum, growth habit and ascomata. c Thallus with loose branchlets and one apothecium. d Juvenile thallus with main branches and perpendicular, spine-like side branchlets. a Schultz 16765 (HBG); b Tønsberg 30493 (BG); c, d Schultz 16762 (HBG). Scale bars $=1 \mathrm{~mm}$
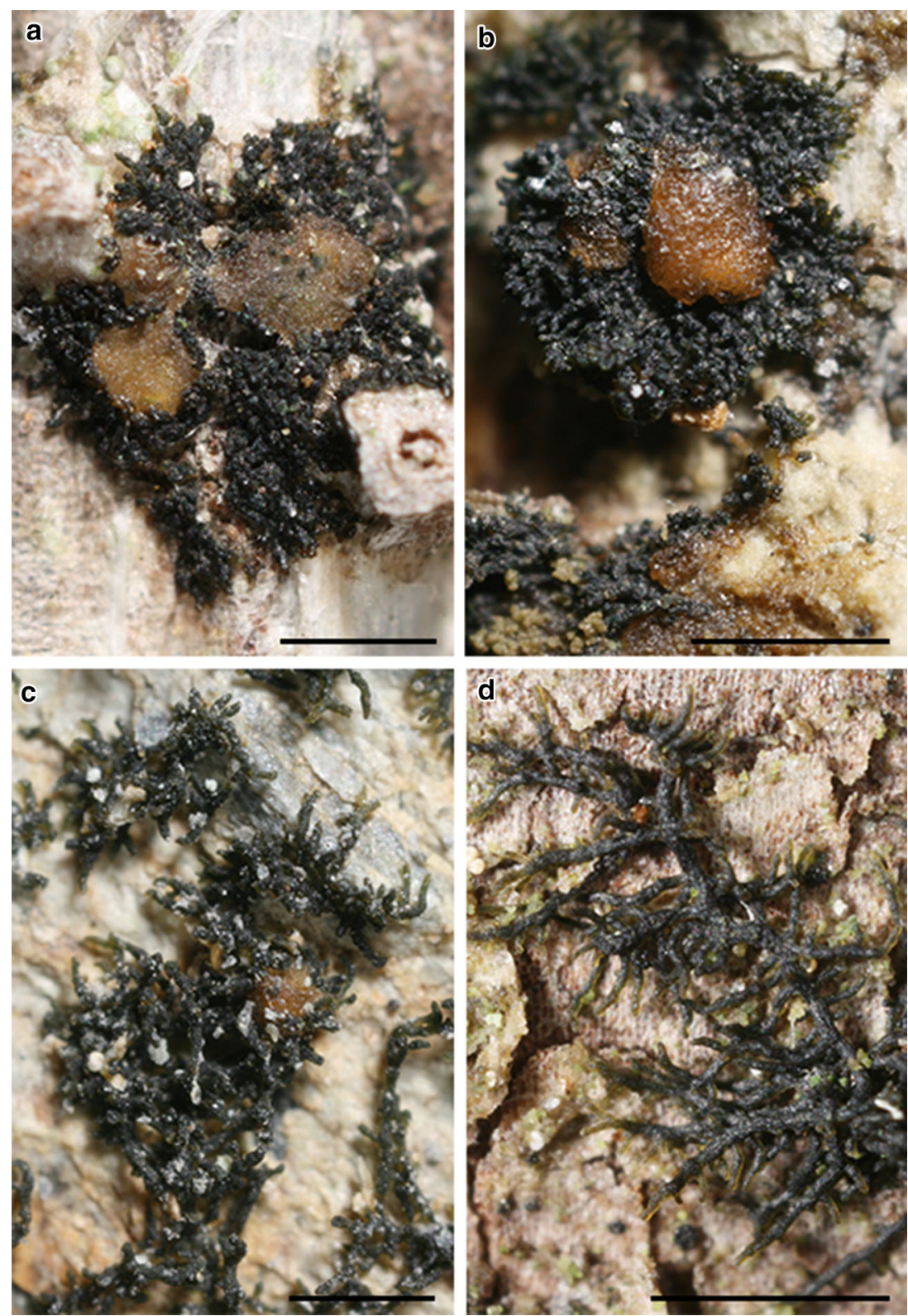

primers MCM7-CalicF and MCM7-CalicR (Prieto et al. 2013). The protein coding RPB1 was amplified using the primers RPB1Af and RPB1Cr (Stiller and Hall 1997) and the RPB2 with RPB2-5F and RPB2-7cR (Liu et al. 1999). Photobionts were also sequenced using CYA $106 \mathrm{~F}$ and 781Ra-b primers for the 16S rRNA region (Nübel et al. 1997) and with CX-CY (Rudi et al. 1998) for the rbcLX region.

PCR amplifications were performed using Illustra $^{\mathrm{TM}}$ Hot Start Mix RTG PCR beads (GE Healthcare, UK) in a $25 \mu \mathrm{l}$ volume, containing $3 \mu \mathrm{l}$ of genomic DNA, $1 \mu \mathrm{l}$ at $10 \mu \mathrm{M}$ of each primer and distilled water. Amplifications were performed using the following program: initial denaturation at $95{ }^{\circ} \mathrm{C}$ for $15 \mathrm{~min}$, followed by $35-40$ cycles of $95{ }^{\circ} \mathrm{C}$ for $45 \mathrm{~s}, 54-56{ }^{\circ} \mathrm{C}$ for $50 \mathrm{~s}, 72{ }^{\circ} \mathrm{C}$ for $1 \mathrm{~min}$, followed by a final extension at $72{ }^{\circ} \mathrm{C}$ for $5 \mathrm{~min}$. PCR products were subsequently purified using the enzymatic method Exo-sap-IT (USB Corporation, Santa Clara, CA, USA). The purified PCR products were sequenced at Macrogen Europe service (www.macrogen.com), using the same amplification primers. Sequences were assembled and edited using Sequencher v. 4.10.1. (Genes Codes Corporation, Ann Arbor) and deposited in GenBank (Electronic Supplementary Material). 

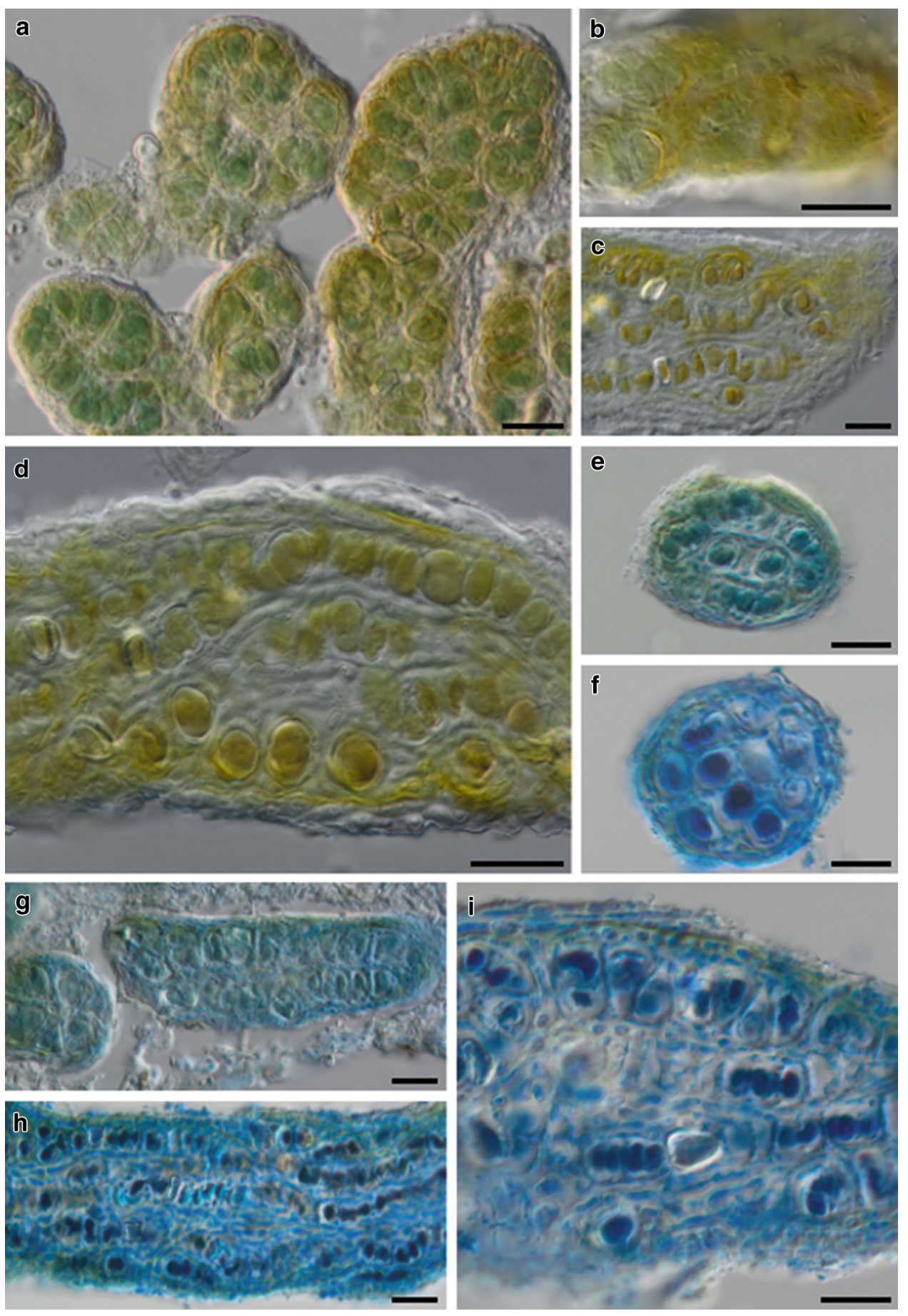

Fig. 2 Vegetative thallus structures and photobiont. a and b Lichin-

branch tip, hyphal collar thicker, two to three rows, same magnifiodium ahlneri, a Cross section of thallus filaments, hyphal collar surrounding cyanobionts threads composed of $1(-2)$ rows of hyaline cells, delicate hyphae surrounding cyanobiont cells in the thallus center; b Surface view showing jigsaw pattern of cells of hyphal collar; c, $\mathbf{d}$ L . sirosiphoideum, c Surface view showing jigsaw pattern of cells of hyphal collar, same magnification as in $\mathbf{b}$, but hyphal cells somewhat larger; d longitudinal section of thick thallus branch, hyphal collar of 2-3 rows, filamentous cyanobiont with intercalary, thick-walled heterocytes and surrounded by irregularly shaped hyphae, fungal haustoria absent; e $L$. ahlneri, cross section of branch tip, hyphal collar thin, one row; $\mathbf{f} L$. sirosiphoideum, cross section of cation as in $\mathbf{e} ; \mathbf{g} L$. ahlneri, longitudinal section of thallus branch, filamentous cyanobiont threads in two rows; $\mathbf{h}, \mathbf{i}$ L. sirosiphoideum, h Longitudinal section of thallus branch, filamentous cyanobiont threads in four rows, same magnification as in $\mathrm{g}$; $\mathbf{i}$ Longitudinal section of main thallus branch, hyphal collar with two to three rows of cells, internal hyphal cells variously shaped, reticulate, cyanobiont threads with thick-walled, intercalary heterocyte. a, b Tønsberg 30493 (BG); c, d, f, i Schultz 16762 (HBG); e, g Schultz 16785 (HBG); h Root 1749b (dupl. HBG). a Water preparation; b-d treated with $5 \% \mathrm{KOH} ; \mathbf{f}-\mathbf{i}$ stained with lactophenol cotton blue. - Scale bars $=20 \mu \mathrm{m}$ 
Fig. 3 Reproductive structures. a-c Lichinodium ahlneri,

a Hymenium with mature asci and ascospores; b Juvenile (right) and fully mature, just opened ascus with ascospores (left); c thin-walled,

prototunicate ascus with eight ascospores; $\mathbf{d} L$.

sirosiphoideum, thin-walled ascus with premature ascospores; e-g L. ahlneri, e cross section of apothecium, proper exciple lacking, apothecium attached to thallus branches by scattered hyphae originating from subhymenium; f thin-walled, prototunicate ascus, no amyloid staining of ascus wall and hymenium gelatin in Lugol's solution; g mature ascus with ascospores (right), apically ruptured ascus (left); $\mathbf{h}$ L. sirosiphoideum, mature, thin-walled ascus; $\mathbf{i}, \mathbf{j} L$. ahlneri, i Pyriform pycnidium developed between thallus filaments; j Filiform conidia produced terminally on simple conidiophores in laterally cut pycnidium. a, e, g, i, j Tønsberg 30493 (BG), b, c Schultz 16785 (HBG), f Rosentreter 19076 (SRP), d, h Schultz 16762 (HBG). a-d, f treated with $5 \%$ $\mathrm{KOH} ; \mathbf{e}, \mathbf{g}-\mathbf{j}$ stained with lactophenol cotton blue. - Scale bars $\mathbf{a}-\mathbf{c}, \mathbf{i}, \mathbf{j}=20 \mu \mathrm{m} ; \mathbf{d}, \mathbf{g}-$ $\mathbf{h}=10 \mu \mathrm{m} ; \mathbf{e}=100 \mu \mathrm{m}$
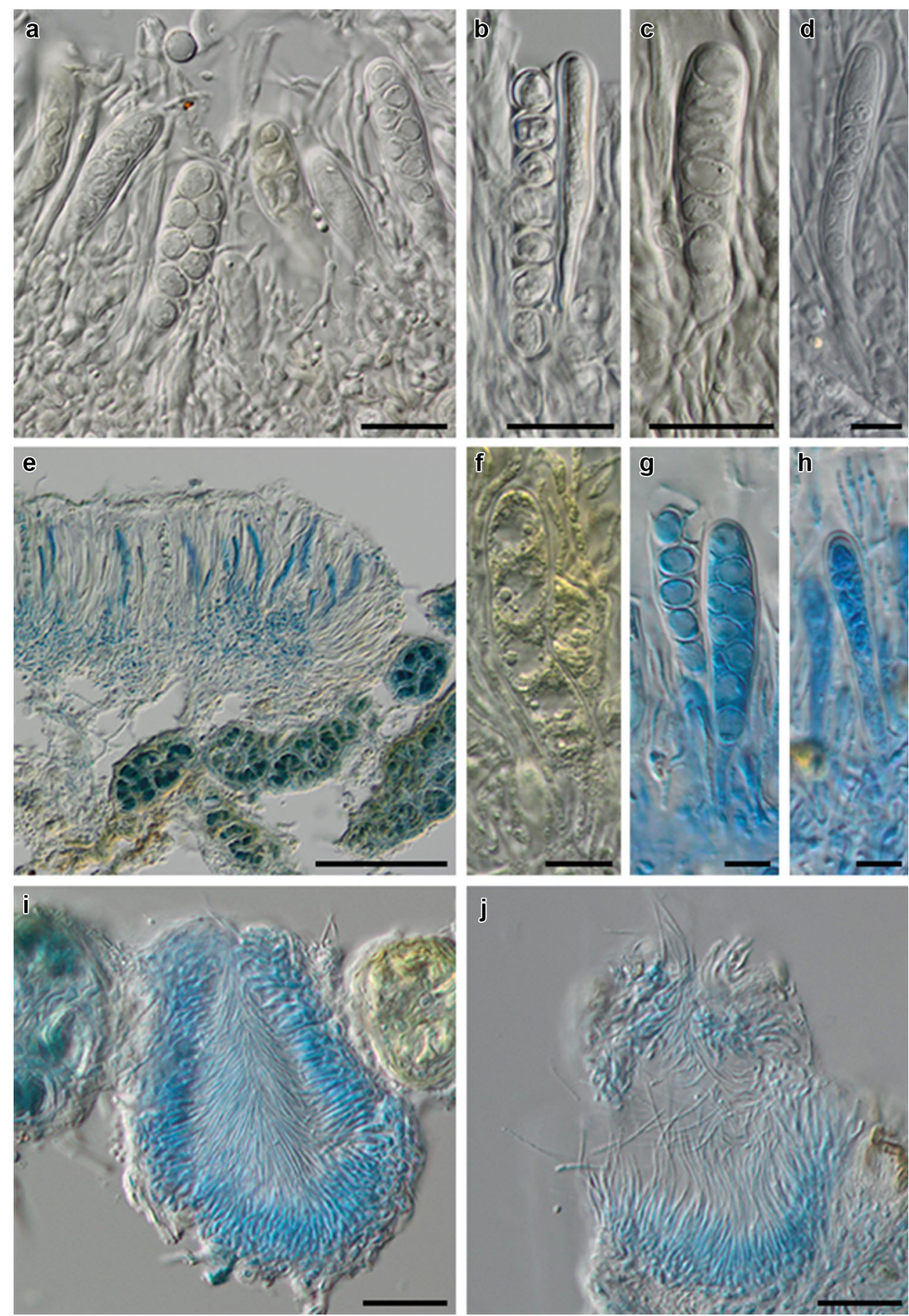

\section{Phylogenetic analyses}

Initial Blast searches were conducted in GenBank (https:// blast.ncbi.nlm.nih.gov/Blast.cgi) with the Lichinodium sequences in order to select the taxon sampling for the phylogenetic analyses. For the first analysis (Pezizomycotina tree) we included six genes but in the second matrix we excluded MCM7 due to missing data (ca. $90 \%$ of missing data). Sequences were aligned manually using
MacClade 4.01 (Maddison and Maddison 2001) and translated to amino acids for protein coding loci. Ambiguous regions (sensu Lutzoni et al. 2000) and introns were delimited manually and excluded from the phylogenetic analyses. Additionally, we used MAFFT v. 6 (Katoh and Toh 2008) to carry out the alignments automatically using the default settings. The alignments were trimmed to exclude ambiguously aligned regions using Gblocks $0.91 \mathrm{~b}$ (Castresana 2000) and following the relaxed conditions 
described by Talavera and Castresana (2007). Since the Maximum Likelihood results were very similar between MAFFT-Gblocks and manually constructed matrices we used the latter for the rest of analyses.

Each individual gene region was analyzed using maximum likelihood-based inference (ML) as implemented in RAxML ver. 8.1.11 (Stamatakis 2014) with a GTRGAMMA model for tree inference. Bootstrapping was performed with a GTRCAT model and 1000 replicates. In order to check for gene-tree incongruence, we compared Maximum Likelihood bootstrap values (ML-BS) between the individual gene trees. Clades were considered in conflict when a supported clade (bootstrap support $>70 \%$ ) for one marker was contradicted with significant support by another. Because no supported nodes were in conflict, the data were combined into a single concatenated data matrix. To select models and partitions, the concatenated matrices were subjected to a greedy algorithm (Lanfear et al. 2012) using the AICc in PartitionFinder v. 2.1.1 (Guindon et al. 2010; Lanfear et al. 2017).

The first combined Maximum Likelihood (ML) analysis was run with ten distinct partitions (nuLSU, nuSSU, mtSSU, 1st position of RPB1 and RPB2, 2nd position RPB1 and RPB2, 3rd position of RPB1, 3rd position of RPB2, 1st position of MCM7, 2nd position of MCM7 and 3rd position of MCM7), using a GTRGAMMA model of molecular evolution and rate heterogeneity with unlinked parameters and 1000 bootstrap replicates. For the second analysis we used the same parameters with eight distinct partitions (nuLSU, nuSSU, mtSSU, 1st position of RPB1, 1st position of RPB2, 2nd position of RPB1, 2nd position of RPB2, 3rd position of RPB1 and RPB2). The GTR model (Rodríguez et al. 1990) with an estimated proportion of invariable sites and with a gamma distribution was selected for all partitions in both analyses except for the 3rd position of the RPB1 in the first analysis which corresponded to a SYM model (Zharkikh 1994) with an estimated proportion of invariable sites and with a gamma distribution and for the 2nd position of the RPB2 in the second analysis, which corresponded to a GTR model with a gamma distribution.

Bayesian inference was carried out for the two matrices through Markov Chain Monte Carlo (MCMC) sampling, as implemented in MrBayes 3.2.6 (Ronquist et al. 2011). The analyses consisted of two parallel searches, each with four chains, run for $10 \mathrm{M}$ generations, and initiated with a random starting tree. The chains were sampled every 100 generations from the posterior distribution. A burn-in sample of 25,000 trees was discarded for each run. The remaining 150,000 trees (pooled from both independent runs) were used to assemble a majority rule consensus tree and to estimate branch lengths and posterior probabilities (PPs). To determine if the chains had converged, verify if mixing was appropriate, and choose a suitable burn-in, we plotted the log-likelihood values against the time generation with Tracer v.1.5.0 (Rambaut and Drummond 2007). We assumed stationarity of the chains when log-likelihood values reached the same stable equilibrium value for each independent run (Huelsenbeck and Ronquist 2001) and when average standard deviation of split frequencies across runs dropped below 0.01 . We also tested the convergence with the AWTY program (Wilgenbusch et al. 2004; Nylander et al. 2008). Maximum likelihood, Bayesian analyses and the selection of models were run on the CIPRES Science Gateway v. 3.3 (Miller et al. 2010).

Cyanobiont sequences were subjected to Blast in GenBank (https://blast.ncbi.nlm.nih.gov/Blast.cgi) and the closest matches were downloaded in order to construct a phylogenetic tree. This phylogenetic tree was constructed using the $16 \mathrm{~S}$ and rbcLX regions combined and analyzed with maximum likelihood in RAxML with three partitions (16S, first and second position of the rbcLX and third position of the rbcLX) checking partitions, comparing congruence between gene regions and using the same settings as in the previous analyses.

\section{Light microscopy and transmission electron microscopy (TEM)}

In order to compare Lichinodium with the externally similar filamentous cyanolichen Ephebe lanata (L.) Vain. (Lichinaceae, Lichinomycetes), freezing microtome sections of $14-16 \mu \mathrm{m}$ thick, stained with lactophenol cotton blue and fixed in glycerine were produced. The anatomy of the vegetative thallus, reproductive structures and especially the symbionts' interface were studied employing an Olympus BX51 compound microscope set to differential interference contrast (DIC) and equipped with an Olympus XC50 camera to obtain digital images. Sample preparation for transmission electron microscopy (TEM) was performed according to Büdel and Riehl (1987). Lichen thallus fragments of $1-3 \mathrm{~mm}$ were soaked in water overnight before they were fixed with $1 \%$ glutaraldehyde in cacodylate buffer $(50 \mathrm{mM}, \mathrm{pH} 7.0)$ for $5 \mathrm{~h}$ at $4{ }^{\circ} \mathrm{C}$ and postfixed with $1 \%$ osmium tetroxide for $1 \mathrm{~h}$ at $4{ }^{\circ} \mathrm{C}$. The samples were dehydrated through a series of graded acetone concentrations, $30-100 \%$, and finally embedded in plastic according to Spurr (1964). Ultrathin sections were obtained with an ultramicrotome (Ultracut E, Leica-Reichert-Jung, Nußloch, Germany) and stained with uranyl acetate followed by lead citrate (Reynolds 1963). Sections were viewed with a LEO 906 E TEM (LEO, Oberkochen, Germany)—operated at $100 \mathrm{kV}$-equipped with a MultiScan CCD Camera (Model 794) of Gatan (Munich, Germany) and using Digital Micrograph software version 
2.0.2. from Gatan to acquire, visualize, analyze, and process image data.

\section{Results}

A total of 25 mycobiont and 10 cyanobiont sequences were generated for this study (Electronic Supplementary Material, Figs. 4-6). The combined data set of the first matrix consisted of 69 taxa and 4898 unambiguously aligned sites, 1297 for the nuSSU, 963 for the nuLSU, 610 for the mtSSU, 518 for the RPB1, 946 for the RPB2 and 564 for the MCM7. The second matrix consisted of 91 taxa with 5085 unambiguously aligned sites, 1133 for the nuSSU, 1196 for the nuLSU, 588 for the mtSSU, 516 for the RPB1 and 1652 for the RPB2. The photobiont matrix consisted of 39 taxa with 867 unambiguously aligned sites, 575 for the $16 \mathrm{~S}$ region, and 292 for the rbcLX.

\section{Mycobionts}

The best maximum likelihood trees with bootstrap support and posterior probabilities from the two analyses (Bayesian and ML) are depicted in Figs. 4 and 5 respectively. In the Pezizomycotina tree (Fig. 4) all major taxonomic groups are supported; Lichinodium is the sister group to the sampled representatives of Leotiomycetes, and together they form a supported clade which is sister to Sordariomycetes and Laboulbeniomycetes. Trizodia acrobia, previously placed as the sister to the Leotiomycetes (Stenroos et al. 2010), is related to Coniocybomycetes, Lichinomycetes and Candelariomycetes in our analyses (only supported by Bayesian analysis). Xylonomycetes is supported as related with Leotiomycetes, Sordariomycetes, Laboulbeniomycetes, Arthoniomycetes and Dothideomycetes. Lecanoromycetes is sister to Eurotiomycetes, and Lichinomycetes is sister to Coniocybomycetes, both related with Candelariomycetes and Trizodia.

In the second analysis, with a considerably larger taxon sampling of Sordariomyceta (Fig. 5), Laboulbeniomycetes, Sordariomycetes and Leotiomycetes are monophyletic and form a monophyletic clade (Sordariomyceta sensu Schoch et al. 2009a). Lichinodium is nested within Leotiomycetes and is sister to a clade comprising Leotia lubrica and $\mathrm{Mi}$ croglossum rufum (Leotiales). It can be noted that Helotiales were non-monophyletic, as were also the families Dermataceae, Helotiaceae, Myxotrichaceae, Pseuderotiaceae and Rutstroemiaceae. Rhexocercosporidium sp. is related to Cadophora sp. (Ploettnerulaceae). Some members of Pseudeurotiaceae and Myxotrichaceae (i.e. Pseudeurotium, Pseudogymnoascus and Leuconeurospora) form a clade with Thelebolales. Sclerotiniaceae is monophyletic (although only a few members were included) and is related to Rutstroemiaceae and Cenangiaceae. The order Triblidiales forms a clade with some members of the order Rhytismatales.

\section{Cyanobionts}

Sequences of the cyanobionts in L. ahlneri and L. sirosiphoideum were obtained for both $16 \mathrm{~S}$ and rbcLX genes. The 16S sequences of the samples SL84, SL91, SL92 ( $L$. sirosiphoideum) had an identification match and cover of $100 \%$ with the cyanobacterial sequence of Rhizonema sp. "cyanobiont of Lichinodium sp." found in the study of Cornejo and Scheidegger (2016) in Newfoundland (Canada); and the sequences of the samples SL150 ( $L$. sirosiphoideum) and SL152 (L. ahlneri) had an identification match of $99 \%$ and $100 \%$ cover with Rhizonema sp. "cyanobiont of Coccocarpia sp." (KF359680) from Kenya from Kaasalainen et al. (2015), and Rhizonema sp. of Coccocarpia palmicola (EU818950) from Costa Rica described as Rhizonema by Lücking et al. (2009). The rbclX sequences of samples SL84, SL90, SL91 and SL150 (L. sirosiphoideum) had an identification match of $100 \%$ with a $97 \%$ cover with Rhizonema sp. "cyanobiont of Erioderma pedicellatum" found in the study of Cornejo and Scheidegger (2016) in Newfoundland (Canada). Sequence SL152 (L. ahlneri) had a 99\% identity and 99\% cover with Nostoc sp. of Stereocaulon fronduliferum (DQ266030) found in the study of Stenroos et al. (2006) from New Zealand. The best tree from the Maximum Likelihood analysis is depicted in Fig. 6. The sequences of the Lichinodium cyanobionts formed a well-supported clade with members of the Rhizonema clade described and later validated by Lücking et al. (2009, 2014).

\section{Light microscopy and transmission electron microscopy (TEM)}

The general constitution of the lichen thallus as described by Henssen (1963, 1974) for Lichinodium and Ephebe based on light microscopy is confirmed. However, the very short and rather vague description of the Lichinodium haustoria provided by Henssen (1963) as "unverdickt" (i.e. not thickened) cannot be confirmed. Despite intensive search, the nature of the symbiont contact could not be elucidated by light microscopy. However, our TEM observations in L. ahlneri and L. sirosiphoideum were congruent and revealed that true haustoria are in fact absent. The twisted threads of the Rhizonema cyanobionts are surrounded by an outer hyphal collar composed of 1-3 rows of somewhat elongated mycobiont cells and an inner network of small-celled hyphae (Fig. 7a, b). The latter hyphae produce short to elongated and tapering projections that are $150-200 \mathrm{~nm}$ thick at their tips. Many vesicles are 


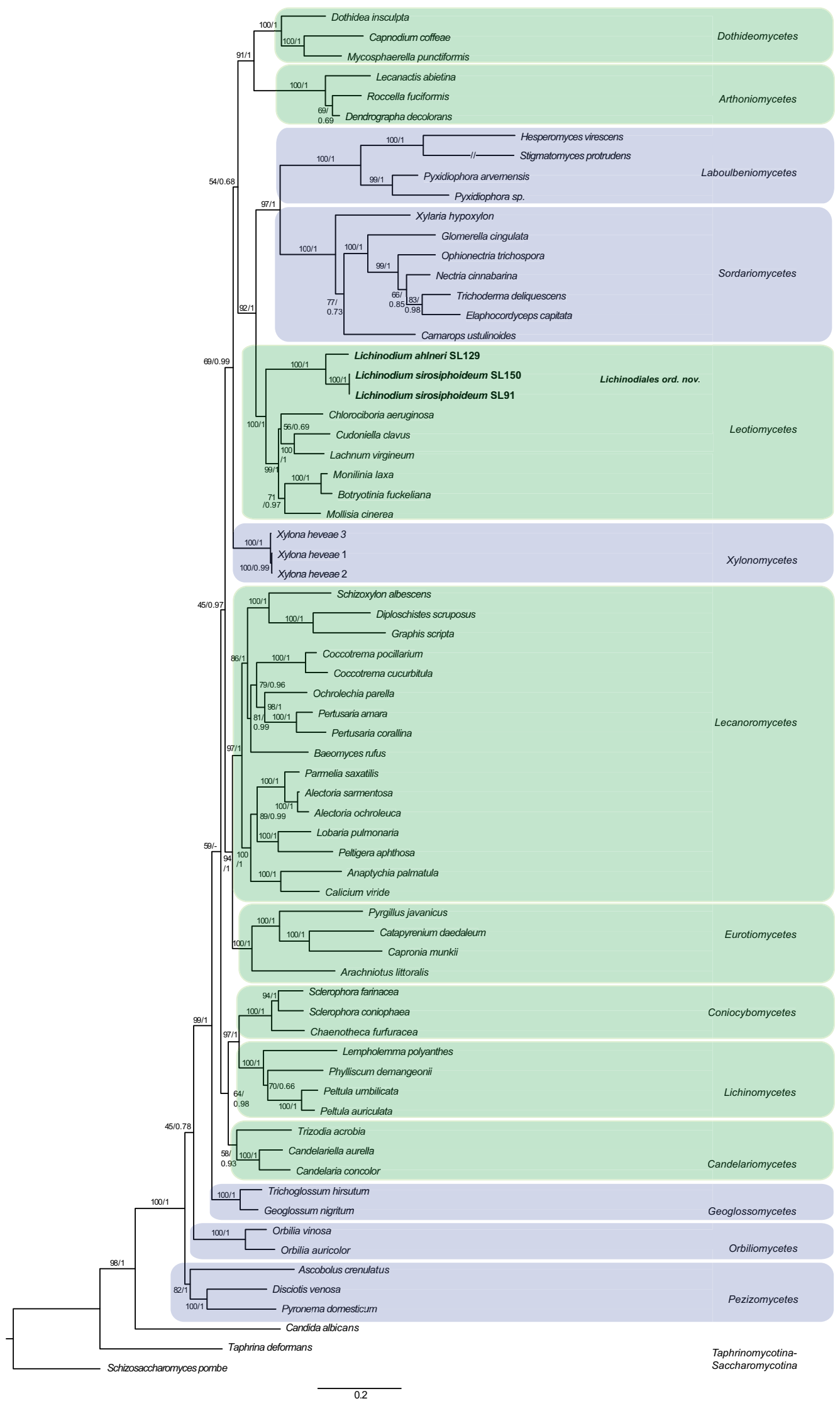


4Fig. 4 Best tree obtained from RAxML based on a 6-locus data set (nuLSU, nuSSU, mtSSU, MCM7, RPB1 and RPB2) for the first analysis (Ascomycota tree). Nodes show bootstrap support (ML-BS) from Maximum Likelihood and posterior probabilities (PP) obtained in the Bayesian analysis, ordered as ML-BS/PP. Classes containing lichenized members are in green; classes lacking known lichenized members are in blue

released into the gelatinous matrix where these tips touch the contact zone of the cells of the Rhizonema thread indicating enzymatic activity. This results in a loose connection of neighbouring cells that were previously tightly adhering together (Fig. 7a, b). The cells separate and the resulting space gives way to the mycobiont projections to penetrate even further between the cyanobiont cells. Thereby, an extensive interface for the symbiotic partners is established allowing metabolite and signal transfer. This contact of the symbiont partners has been observed in all studied samples of Lichinodium. In contrast, typical robust finger-like haustoria causing conspicuous indentions of the cyanobiont cell wall have been observed in Ephebe lanata in transmission electron microscopy (Fig. 7c, d).

\section{Discussion}

The inclusion of Lichinodium in Leotiomycetes is very unexpected, as so far, no lichen-forming fungi were known in this major group of Ascomycota (Lücking et al. 2016). Several lichenized groups have formerly been included in Helotiales within the Leotiomycetes (i.e. Baeomycetaceae and Icmadophilaceae [Rambold et al. 1993]) but this was rectified when molecular phylogenies revolutionized fungal systematics (Stenroos et al. 2002) and showed both families to belong to Lecanoromycetes. The Leotiomycetes is a diverse class of Pezizomycotina where the evolutionary history is not resolved and the classification within the class is thus still unsettled (Wang et al. 2006a, b; Zhang and Wang 2015). Morphologically the Leotiomycetes is a highly diverse group, which primarily produces small apothecioid ascomata with an exposed hymenium and inoperculate unitunicate asci with an apical perforation pore for releasing the spores (Wang et al. 2006b). An apical ring may be present or not. The apothecioid small ascomata in Lichinodium are similar to those present in other Leotiomycetes, but differ from the rest of Lichinomycetes in being essentially immarginate, and without a well-formed lecanorine, zeorine or biatorine margin as usual in Lichinomycetes (Fig. 1). The previous classification of Lichinodium in the Lichinomycetes was supported by the presence of prototunicate asci, the dominant type of ascus in that class (Henssen 1994, 1995; Schultz and Büdel
2002). The asci in Lichinodium lack an apical apparatus and amyloid structures (Fig. 3), and they passively release the ascospores by the disintegration or rupture of the upper ascus wall. Whereas similar ascus types have been reported for at least some families within Leotiomycetes, the majority of families within this class possess asci with an apical ring structure and euamyloid or hemiamyloid wall opening by an apical split (Jaklitsch et al. 2016).

Although the ascus morphology and dehiscence is diverse in lichens and it has been consequently used in classification (Hafellner 1984), such traits do not always characterize natural and monophyletic groups (e.g. Schmitt et al. 2005; Wedin et al. 2005; Lumbsch et al. 2007; Prieto et al. 2013). Prototunicate asci, which characterized the order Caliciales (see the historical overview in Tibell 1984), are present in many distantly related groups of Ascomycota, and have clearly been acquired multiple times from ancestors with an apical dehiscence apparatus and active spore dispersal (Tibell 1984; Wedin and Tibell 1997; Schoch et al. 2009a; Prieto et al. 2013). Here we also show that prototunicate asci have been acquired independently in another lichen lineage within the Leotiomycetes, probably through the loss of apical structures.

Lichinodium is not only the first confirmed lichenforming genus within the Leotiomycetes representing another independent origin of lichenization but it also constitutes an example of the parallel evolution of filamentous lichens. Filamentous lichens are extremely rare among the Ascomycota and have evolved independently within several classes associating with different photobionts (i.e. cyanobacteria in Lichinomycetes, Eurotiomycetes and Leotiomycetes, green algae in Dothideomycetes and both groups of photobionts in Lecanoromycetes). Despite a general resemblance in the thread-like external thallus shape in filamentous lichens, that is largely determined by the photobiont partner, light microscopy and TEM studies revealed distinct differences in the symbionts' interface. Lichinodium lacks true haustoria typically observed in members of the Lichinaceae (Lichinomycetes) with unicellular cyanobionts (Büdel and Riehl 1987). Our investigations also confirm the presence of such haustoria in the thread-like cyanolichen Ephebe lanata in the Lichinomycetes, which possesses the filamentous Stigonema as cyanobiont. In Lichinodium, however, haustoria are absent and instead, thallus hyphae appear between the cyanobiont cells without penetrations of the photobiont cell wall. Haustoria have also been described in members of the Lichinomycetes as in Lempholemma spp. (Schiman-Czeika 1987), in Euopsis granatina (Sommerf.) Nyl. (Büdel and Henssen 1987), in Heppia (as appressoria, Büdel 1987) or in Thermutis velutina (Ach.) Flot. (as finger-like invaginations, Henssen 1963). In other filamentous lichens with Trentepohlia, no 
Fig. 5 Best tree obtained from

RAxML based on a 5 locus data set (nuLSU, nuSSU, mtSSU,

RPB1 and RPB2) for the second analysis (Sordariomyceta tree). Nodes show bootstrap support (ML-BS) from maximum likelihood and posterior probabilities (PP) obtained in the Bayesian analysis, ordered as ML-BS/PP. Orders and families for the Leotiomycetes are based on Jaklitsch et al. (2016)

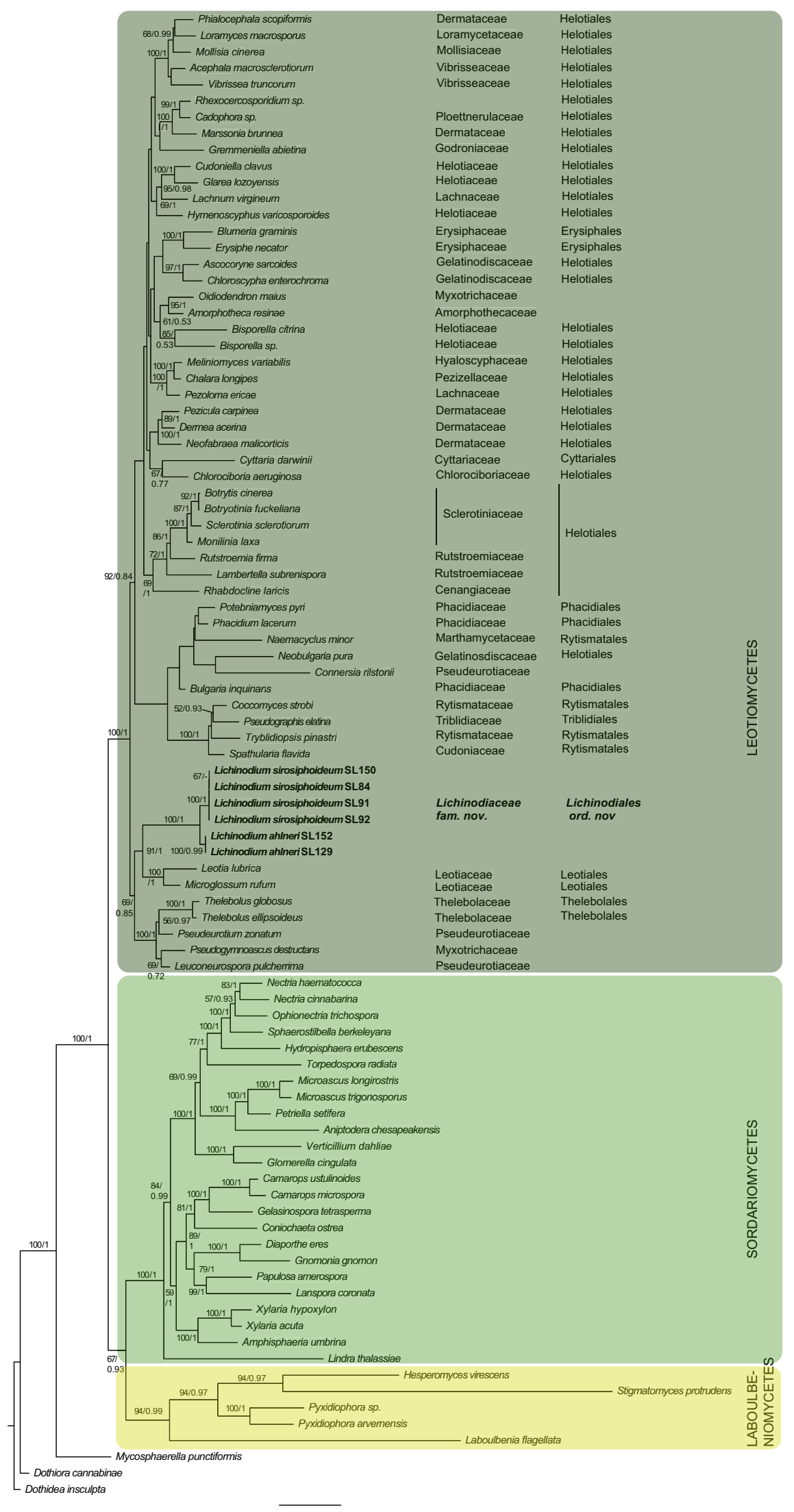


Fig. 6 Best tree obtained from RAxML for the cyanobiont analysis resulting from the combination of the $16 \mathrm{~S}$ and rbcLX genes. Nodes show bootstrap support (ML-BS) from maximum likelihood and posterior probabilities (PP) obtained in the Bayesian analysis, ordered as ML-BS/PP. GenBank accession numbers for newly produced sequences are shown in boldface. Details for these specimens are included in the Electronic Supplementary Material
KT867611/KT883991 ex Lichinodium sp. Canada

KT867612/KT883992 exLichinodium sp.Canada

KT867616/KT883996 ex Lichinodium sp.Canada

KT867613/KT883993 ex Lichinodium sp.Canada

KT867614/KT883994 ex Lichinodium sp.Canada

MK225518/MK228125 SL150 ex Lichinodium sirosiphoideum Alaska

99/0.96 MK225522/MK228128 SL92 ex Lichinodium sirosiphoideum Norway

- KT867610/KT883990 ex Lichinodium sp. Canada

MK225520/MK228126 SL84 ex Lichinodium sirosiphoideum Alaska

$61 / 0.88$

MK225521/MK228127 SL91 ex Lichinodium sirosiphoideum Sweden

DQ266030/DQ265951 ex Stereocaulon fronduliferum New Zealand

65

$47 /-$

76 KT867624/KT884002 ex Parmeliella parvula Canada

MK225519/MK228126 SL152 ex Lichinodium ahlneri Norway

EU818950 ex Coccocarpia palmicola Costa Rica

40/- KT867573/KT883978 ex Coccocarpia palmicola Canada

KT867570/KT883975 ex Coccocarpia palmicola Canada

KT867561/KT883966 ex Coccocarpia palmicola Canada

KT867562/KT883967 ex Coccocarpia palmicola Canada

KT867560/KT883965 ex Coccocamia palmicola Canada

KT867563/KT883968 ex Coccocarpia palmicola Canada

KT867566/KT883971 ex Coccocarpia palmicola Canada

$6 / 0.77$

KT867575/KT883980 ex Erioderma pedicellatum Canada

KT867572/KT883977 ex Erioderma pedicellatum Canada

KT867574/KT883979 ex Erioderma pedicellatum Canada

$65 / 0.59$

EU818954 ex Dictyonema glabratum Costa Rica

EU818948 ex Coccocarpia filiformis Costa Rica

$100 / 1$

$52 /-$

$100 / 1$

DQ185280/DQ185223 Nostoc commune

$\frac{92}{11}$

100/1 KT897721/KT884014 ex Peltigera collina Canada

K KT87718/KT884011 ex Lobaria pulmonaria Canada

97

EU818960 ex Dictyonema hemandezii Costa Rica

EU818949 ex Coccocarpia palmicola Costa Rica

EU818952 ex Dictyonema aeruginosulum Costa Rica

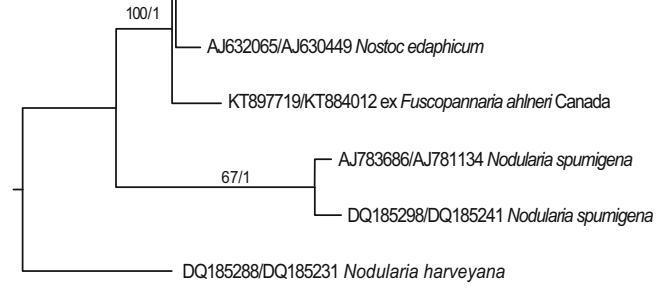



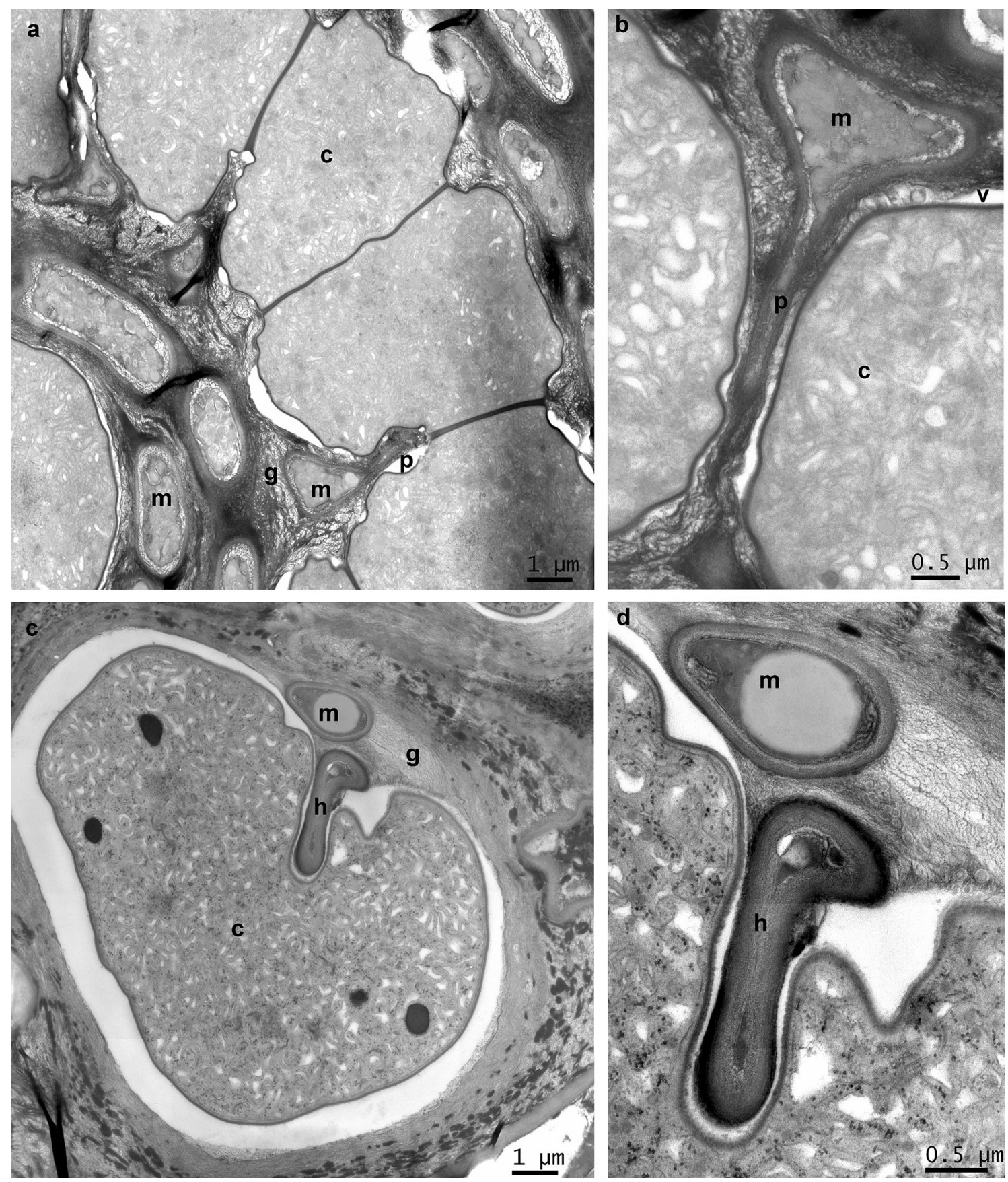

Fig. 7 a TEM image illustrating the composition of the fungal and cyanobacterial symbionts in Lichinodium sirosiphoideum (Root1749b_02) at $\times 6000$ magnification. Large-celled chain of the cyanobiont Rhizonema (c) running from top left to bottom right surround by short-celled mycobiont cells $(\mathrm{m})$ embedded in gelatinous matrix ( $\mathrm{g}$ ), some hyphae with projections (p) running between neighbouring cyanobiont cells. b TEM image showing details of the mycobiont-cyanobiont interface in Lichinodium sirosiphoideum (Root1749b_11) at $\times 12,930$ magnification. Mycobiont hyphal cell (top) with elongated, tapering projection intruding the space between two neighbouring cyanobiont cells (left, right) as a result of enzymatic activity indicated by numerous vesicles (v) released into the gelatinous matrix embedding the symbionts. c TEM image illustrating composition of the fungal and cyanobacterial symbionts in Ephebe lanata (Schultz08592_02) at $\times 6000$ magnification. A large Stigonema cyanobiont cell invaginated by a robust, finger-like fungal haustorium (h) originating from a short-celled, vacuolized mycobiont cell, symbionts embedded in massive gelatinous matrix, white space between cyanobiont protoplast and gelatinous outer coat due to shrinking during preparation. d TEM image showing details of fungal haustorium entering the Stigonema cyanobiont in Ephebe lanata (Schultz08592_02a) at $\times 16,700$ magnification. Numerous vesicles in a gelatinous matrix (middle) are released from the cyanobiont cell wall into a narrow contact space with the mycobiont haustorium, indicating metabolite exchange 
haustoria have been observed in Coenogonium (Meier and Chapman 1983) but they are present in Physolinum monile (Davis et al. 1989).

In other lichens, the majority of mycobionts do not penetrate the cell wall of their photobiont (Honegger 1986a, b, 1991, 2009) and many different types of mycobiont-photobiont physical relationships occur (including simple wall-to-wall appositions, finger-like or slightly branched intracellular haustoria, and different types of intraparietal haustoria; see Honegger 1991, 2009, 2012). Different patterns have been found depending on the growth form and the photobionts. For example, in cyanobacterial lichens (mainly with Nostoc) intragelatinous fungal protrusions within the gelatinous sheaths of cyanobacterial colonies (Honegger 2012) have been reported and intracellular haustoria have been claimed to occur exclusively in relatively primitive non-stratified crustose lichens (Honegger 1991). However, it is not clear if the different types of physical mycobiont-photobiont contacts are conserved in the evolution of Fungi (Honegger 1991, 2012) and more studies should be carried out.

Ecologically, the Leotiomycetes is very diverse, including various lifestyles such as plant pathogens, endophytes, ectomycorrhizal and ericoid mycorrhiza formers, aquatic or terrestrial saprobes, and nematode trappers (Wang et al. 2006b). Considering the ecological radiation of the Leotiomycetes and the shifts between strategies, the switch into lichenization supports the idea that lifestyle and ecological factors are critical in shaping the evolutionary history of the helotialean fungi/Leotiomycetes (Wang et al. 2006a) and driving the high morphological diversity observed, which is reflected in the phylogeny (e.g. polytomies and long branches). Although a comprehensive sampling of the Leotiomycetes has been here analyzed with 5 gene regions (including protein coding genes), this sampling is still very far from complete. Despite this, the results show a high level of polyphyly where the morphology-based taxonomy hardly matches the phylogenetic results and needs to be further studied genetically and rearranged taxonomically. Thus, Helotiales is not a natural group as it has been previously demonstrated (Wang et al. 2006a, b; Zhang and Wang 2015). The families Dermataceae, Helotiaceae, Myxotrichaceae, Pseudeurotiaceae, and Rutstroemiaceae are also not monophyletic, which is here suggested for the first time for the three last families (Wang et al. 2006b). Phialocephala and Marssonia should be excluded from Dermataceae. Possible relationships are with Loramycetaceae or Ploettnerulaceae respectively, but this needs further study. Several members of Pseudeurotiaceae and Pseudogymnoascus (Myxotrichaceae) are related to Thelebolales, suggesting that this relationship should be studied further and more species included in future analyses. Our results support the suggestion of Wang et al. (2006b) that a new order should be created for the clade comprising Sclerotiniaceae, Rutstroemiaceae and Cenangiaceae (previously Hemiphacidiaceae). Several taxa not earlier placed phylogenetically are included here. Thus, Amorphotheca and Oidiodendron (both without order) are sisters and the order Triblidiales is here confirmed as belonging to Leotiomycetes as it was previously suggested based on morphology (Jaklitsch et al. 2016).

Lichinodium is sister to Leotiaceae. The latter comprises terrestrial species with stipitate, clavate to globose ascomata that establish symbiotic associations with vascular plants (Kühdorf et al. 2015). Lichinodium however includes chiefly corticolous and saxicolous lichen species that may also grow on other lichens and mosses. Leotiaceae also include species with a symbiotic lifestyle, which suggests that the common ancestor of Leotiaceae and Lichinodium could be symbiotic. Gelatinized apothecia are another character shared between Leotiaceae and Lichinodium, but this trait is present in other Leotiomycetes lineages too. Our results support the recognition of the Leotiales and Leotiaceae in a strict sense including Leotia, Microglossum and Thuemenidium. However the inclusion of Geoglossomycetes in this group suggested by Jaklitsch et al. (2016) is not supported (Fig. 4; Schoch et al. 2009a, b).

Stenroos et al. (2010) suggested that Trizodia, a fungus forming a tripartite association with Sphagnum and cyanobacteria, was related to the Leotiomycetes. The position of this "borderline" lichen in the Ascomycota tree was shown to be sister to Leotiomycetes, although without support (Stenroos et al. 2010). In our analysis, Trizodia does not belong to Leotiomycetes and is not even closely related to it, but is instead closely related to the Candelariomycetes, an early diverging lichen group with an unsettled position within Ascomycota (Schoch et al. 2009a; Prieto et al. 2013; Miadlikowska et al. 2014; Voglmayr et al. 2019). This placement is not fully supported phylogenetically and not sustained by morphological and anatomical characters; thus, it should be confirmed within a more comprehensive phylogenetic framework. Another borderline lichen in the Leotiomycetes was attributed to the genus Cudoniella, i.e. C. brasiliensis Rizz. (Toledo Rizzini 1952). Cudoniella brasiliensis was described as associated with Pleurococcus vulgaris, but lacking a true thallus. Toledo Rizzini stated that $C$. brasiliensis was closely related to Baeomyces, but differing in the "fleshy nature of the apothecia". In our view, the presence of an algal associate and the description by Rizzini strongly suggest that $C$. brasiliensis is closer to Baeomyces than to Cudoniella. Regrettably, ascal characters were not described in detail by Toledo Rizzini, and an ultimate placement of $C$. brasiliensis cannot be provided yet. 


\section{Cyanobionts}

The sequences of Lichinodium cyanobionts correspond to Rhizonema, which are more closely related to the Nostocaceae and Stigonemataceae than to the Scytonemataceae. The genus Rhizonema was described for species of cyanobacteria occurring in tropical basidiomycetous and ascomycetous lichen genera (Lücking et al. 2009, 2014) and was later found in an epiphytic liverwort-lichen community in Canada (Cornejo and Scheidegger 2016). Our samples form a clade with the cyanobionts found in epiphytic Lichinodium specimens from boreal forests in Canada, and with the cyanobionts of Parmeliella parvula and Stereocaulon fronduliferum from the same habitats. All these samples were proposed to belong to a cyanobacteriamediated guild (Cornejo and Scheidegger 2016) in which several species act as reservoir of Rhizonema photobionts (i.e., Frullania asagrayana, Coccocarpia palmicola and Parmeliella parvula) since the Rhizonema species has not been found free-living. Our results add several new habitats for Rhizonema and also increase its distributional area, since it is here reported for the first time in Europe (Norway and Sweden). These results partially support the study of Cornejo and Scheidegger (2016) in which clades were not related with sampling sites but with lichen species. The inclusion of our saxicolous and sexually reproducing specimens may provide further insights into these cyanobacterial guilds and should be studied from an ecological point of view.

\section{Taxonomy}

As shown here and in earlier studies, the unresolved phylogeny of the Leotiomycetes results in a classification that is not yet well settled, and in a number of non-monophyletic groups currently accepted as orders and families (Wang et al. 2006a, b; Zhang and Wang 2015; Jaklitsch et al. 2016). Lichinodium possesses unique characters distinguishing it from the Leotiales and Leotiaceae (Leotia, Microglossum and Thuemenidium) with which it is related. Members of the Leotiaceae have stipitate-capitate ascomata and inoperculate asci with an often apical amyloid ring and typically septate spores. Some, probably most, Leotiales are mycorrhiza-forming (Kühdorf et al. 2015). On the contrary, Lichinodium produces sessile, disc-shaped ascomata, prototunicate asci with simple spores, and is lichenized. Lichinodium cannot be accommodated in any of the described higher taxa within this class due to the unique morphological and ecological characters. The inclusion of Lichinodium into Leotiomycetes thus requires the description of a new family and order, which we do below.

\section{Lichinodiales M. Prieto, M. Schultz, Olariaga \& Wedin ord. nov. MB828666}

Order of inoperculate ascomycetes associated with symbiotic, photoautotrophic cyanobacteria of the genus Rhizonema. Ascomata apothecioid, lacking both a welldeveloped proper exciple and a thalline margin. Hymenium gelatinous, with septate paraphyses and cylindrical, prototunicate and non-amyloid asci with croziers. Ascospores simple, hyaline, globose to subglobose, 8 per ascus, passively released. Conidiomata pycnidial. Conidia filiform, terminally produced on simple conidiophores.

\section{Lichinodiaceae M. Prieto, M. Schultz, Olariaga \& Wedin fam. nov. MB828667}

Lichen-forming ascomycetes associated with Rhizonema cyanobionts and with preference for cool, wet or moist habitats, especially conifer twigs. Thallus fruticulose, blackish, forming tiny rosettes or tufts of minute, cylindrical to irregular branches. Branch shape largely determined by the shape of the threads of the cyanobiont. Cyanobiont threads single or up to five in a dense hyphal collar. Hyphae becoming reticulate when growing inside the gelatinous sheath of the cyanobiont and eventually surrounding the individual cyanobiont cells like a network. Distinct haustoria absent, hyphae forming numerous projections that penetrate into the space between neighbouring cyanobiont cells but do not invaginate or penetrate the cyanobiont cell walls. Ascomata and conidiomata developing from entangled hyphae formed between thallus branches and connected to branches by few, undifferentiated hyphae.

Type: Lichinodium Nyl.

\section{Conclusions}

This study has revealed a new lichenized lineage in the fungal tree of life, in a major fungal group previously thought to only comprise non-lichenized species (Sordariomyceta). This contributes to the unravelling of the evolutionary history of the Leotiomycetes helping to understand the ascomycete evolution as a whole and supporting the idea that lichenization has played a key role in the diversification of extant ascomycetes.

Acknowledgements The authors acknowledge Grants 148/2012, 144/2013 and 71/2015 "Lichinomycetes i Sverige" from the Swedish Taxonomy Initiative (Svenska artprojektet) administered by the Swedish Species Information Center (ArtDatabanken), and Grant 2016-03589 from the Swedish Research Council (VR). We are grateful for skilful lab assistance from the Molecular Systematics 
Laboratory at the Swedish Museum of Natural History, in particular to Bodil Cronholm. We also thank Elke Woelken at the Institute of Plant Science and Microbiology of the University of Hamburg for elaborate TEM technical support. Part of the material used in this study was kindly provided to MS by Bruce McCune (Corvallis), Heather Root (Ogden), Roger Rosentreter (Boise) and Tor Tønsberg (Bergen). Further material was collected during a joint field campaign organized by Alaska National Park Service (James Walton) and Oregon State University (Bruce McCune), and at the Nordic Lichen Society excursion in Nord-Trøndelag, Norway 2015, with the help of Håkon Holien.

Open Access This article is distributed under the terms of the Creative Commons Attribution 4.0 International License (http://creative commons.org/licenses/by/4.0/), which permits unrestricted use, distribution, and reproduction in any medium, provided you give appropriate credit to the original author(s) and the source, provide a link to the Creative Commons license, and indicate if changes were made.

\section{References}

Büdel B (1987) Zur Biologie und Systematik der Flechtengattungen Heppia und Peltula im südlichen Afrika. Bibl Lichenol 23:1-105

Büdel B, Henssen A (1987) Trebouxia aggregata and Gloeocapsa sanguinea reported as phycobionts in Euopsis granatina (Lichinaceae). Plant Syst Evol 158:235-241

Büdel B, Riehl E (1987) Studies on the ultrastructure of some cyanolichen haustoria. Protoplasma 139:145-152

Castresana J (2000) Selection of conserved blocks from multiple alignments for their use in phylogenetic analysis. Mol Biol Evol 17:540-552

Cornejo C, Scheidegger C (2016) Cyanobacterial gardens: the liverwort Frullania asagrayana acts as a reservoir of lichen photobionts. Environ Microbiol Rep 8:352-357

Crittenden PD, Llimona X, Sancho LG (2007) Lichenized unicellular cyanobacteria fix nitrogen in the light. Can J Bot 87:1003-1006

Davis JS, Rands DG, Lachapelle M (1989) Heavily lichenized Physolinum (Chlorophyta) from a dimly lit cave in Missouri. J Phycol 25:419-428

Gargas A, Taylor JW (1992) Polymerase chain reaction (PCR) primers for amplifying and sequencing nuclear $18 \mathrm{~S}$ rDNA from lichenized fungi. Mycologia 84:589-592

Grube M, Hawksworth DL (2007) Trouble with lichen: the reevaluation and re-interpretation of thallus form and fruit body types in the molecular era. Mycol Res 111:1116-1132

Guindon S, Dufayard JF, Lefort V, Anisimova M, Hordijk W, Gascuel O (2010) New algorithms and methods to estimate maximum-likelihood phylogenies: assessing the performance of PhyML 3.0. Syst Biol 59:307-321

Hafellner J (1984) Studien in Richtung einer natürlicheren Gliederung der Sammelfamilien Lecanoraceae und Lecideaceae. Nova Hedwig Beih 79:241-371

Hawksworth DL (1988) The variety of fungal-algal symbioses, their evolutionary significance, and the nature of lichens. Bot J Linn Soc 96:3-20

Hawksworth DL, Santesson R, Tibell L (2011) Racoleus, a new genus of sterile filamentous lichen-forming fungi from the tropics, with observations on the nomenclature and typification of Cystocoleus and Racodium. IMA Fungus 2:71-79

Henssen A (1963) Eine Revision der Flechtenfamilien Lichinaceae und Ephebaceae. Symb Bot Ups 18:1-123

Henssen A (1974) New or interesting cyanophilic lichens II. Lichenologist 6:106-111
Henssen A (1977) The genus Zahlbrucknerella. Lichenologist 9:17-46

Henssen A (1994) Contribution to the morphology and species delimitation in Heppia sensu stricto (lichenized Ascomycotina). Acta Bot Fenn 150:57-73

Henssen A (1995) The new lichen family Gloeoheppiaceae and its genera Gloeoheppia, Pseudopeltula and Gudelia (Lichinales). Lichenologist 27:261-290

Herrera-Campos M, Huhndorf S, Lücking R (2005) The foliicolous lichen flora of Mexico IV: a new, foliicolous species of Pyrenothrix (Chaetotyriales: Pyrenotrichaceae). Mycologia 97:356-361

Honegger R (1986a) Ultrastructural studies in lichens. I. Haustorial types and their frequencies in a range of lichens with trebouxioid phycobionts. New Phytol 103:785-795

Honegger R (1986b) Ultrastructural studies in lichens. II. Mycobiont and photobiont cell wall surface layers and adhering crystalline lichen products in four Parmeliaceae. New Phytol 103:797-808

Honegger R (1991) Fungal evolution: symbiosis and morphogenesis. In: Margulis L, Fester R (eds) Symbiosis as a source of evolutionary innovation. MIT Press, Cambridge, pp 319-340

Honegger R (2009) Lichen-forming fungi and their photobionts. In: Deising HB (ed) The Mycota. Plant Relationships, vol 5. Springer, Berlin, pp 305-333

Honegger R (2012) The symbiotic phenotype of lichen-forming Ascomycetes and their endo- and epibionts. In: Hock B (ed) The Mycota. Fungal Associations, vol 9. Springer, Berlin, pp 288-339

Huelsenbeck JP, Ronquist F (2001) MRBAYES: Bayesian inference of phylogenetic trees. Bioinformatics 17:754-755

Jaklitsch WM, Baral HO, Lücking R, Lumbsch HT (2016) Ascomycota. In: Frey W (ed) Syllabus of plant families-adolf Engler's syllabus der pflanzenfamilien. Stuttgart, Borntraeger, pp 1-322

Kaasalainen U, Olsson S, Rikkinen J (2015) Evolution of the tRNALeu (UAA) intron and congruence of genetic markers in lichen-symbiotic Nostoc. PLoS ONE 10:e131223

Katoh K, Toh H (2008) Recent developments in the MAFFT multiple sequence alignment program. Brief Bioinform 9:286-298

Kühdorf K, Münzenberger B, Begerow D, Gómez-Laurito J, Hüttl F (2015) Leotia cf. lubrica forms arbutoid mycorrhiza with Comarostaphylis arbutoides (Ericaceae). Mycorrhiza 25:109-120

Lanfear R, Calcott B, Ho SY, Guindon S (2012) PartitionFinder: combined selection of partitioning schemes and substitution models for phylogenetic analyses. Mol Biol Evol 29:1695-1701

Lanfear R, Frandsen PB, Wright AM, Senfeld T, Calcott B (2017) PartitionFinder 2: new methods for selecting partitioned models of evolution for molecular and morphological phylogenetic analyses. Mol Biol Evol 34:772-773

Liu YJ, Whelen S, Hall BD (1999) Phylogenetic relationships among ascomycetes: evidence from an RNA polymerase II subunit. Mol Biol Evol 16:1799-1808

Lücking R, Lawrey JD, Sikaroodi M, Gillevet PM, Chaves JL, Sipman HJM, Bungartz F (2009) Do lichens domesticate photobionts like farmers domesticate crops? Evidence from a previously unrecognized lineage of filamentous cyanobacteria. Am J Bot 96:1409-1418

Lücking R, Barrie FR, Genney D (2014) Dictyonema coppinsii, a new name for the European species known as Dictyonema interruptum (Basidiomycota: Agaricales: Hygrophoraceae), with a validation of its photobiont Rhizonema (Cyanoprokaryota: Nostocales: Rhizonemataceae). Lichenologist 46:261-267

Lücking R, Hodkinson BP, Leavitt SD (2016) The 2016 classification of lichenized fungi in the Ascomycota and Basidiomycotaapproaching one thousand genera. Bryologist 119:361-416 
Lumbsch HT, Huhndorf SM (2010) Myconet volume 14. Part one. Outline of Ascomycota. Fieldiana Life Earth Sci 1:1-42

Lumbsch HT, Schmitt I, Lücking R, Wiklund E, Wedin M (2007) The phylogenetic placement of Ostropales within Lecanoromycetes (Ascomycota) revisited. Mycol Res 111:257-267

Lutzoni F, Wagner P, Reeb V, Zoller S (2000) Integrating ambiguously aligned regions of DNA sequences in phylogenetic analyses without violating positional homology. Syst Biol 49:628-651

Maddison WP, Maddison DR (2001) MacClade: analysis of phylogeny and character evolution, version 4.01. Sinauer, Sunderland

Meier J, Chapman R (1983) Ultrastructure of the Lichen Coenogonium interplexum $\mathrm{Nyl}$. Am J Bot 70:400-407

Miadlikowska J, Kauff F, Högnabba F, Oliver JC, Molnár K, Fraker E, Gaya E, Hafellner J, Hofstetter V, Gueidan C, Otálora MAG, Hodkinson B, Kukwa M, Lücking R, Björk C, Sipman HJM, Burgaz AR, Thell A, Passo A, Myllys L, Goward T, FernándezBrime S, Hestmark G, Lendemer J, Lumbsch HT, Schmull M, Schoch CL, Sérusiaux E, Maddison DR, Arnold AE, Stenroos S, Lutzoni F (2014) Multigene phylogenetic synthesis for the class Lecanoromycetes (Ascomycota): 1307 fungi representing 1139 infrageneric taxa, 312 genera and 66 families. Mol Phyl Evol 79:132-168

Miller MA, Pfeiffer W, Schwartz T (2010) Creating the CIPRES science gateway for inference of large phylogenetic trees. In: Proceedings of the gateway computing environments workshop (GCE), New Orleans, LA, pp 1-8

Muggia L, Hafellner J, Wirtz N, Hawksworth DL, Grube M (2008) The sterile microfilamentous lichenized fungi Cystocoleus ebeneus and Racodium rupestre are relatives of plant pathogens and clinically important dothidealean fungi. Mycol Res 112:50-56

Nübel U, Garcia-Pichel F, Muyzer G (1997) PCR primers to amplify 16S rRNA genes from cyanobacteria. Appl Environ Microbiol 63:3327-3332

Nylander JAA, Wilgenbusch JC, Warren DL, Swofford DL (2008) AWTY (are we there yet?): a system for graphical exploration of MCMC convergence in Bayesian phylogenetics. Bioinformatics 24:581-583

Ozenda P, Clauzade C (1970) Les Lichens. Étude Biologique et Flore Illustrée. Masson \& Cie, Paris

Prieto M, Wedin M (2013) Dating the diversification of the major lineages of Ascomycota (Fungi). PLoS ONE 8:e65576

Prieto M, Baloch E, Tehler A, Wedin M (2013) Mazaedium evolution in the Ascomycota (fungi) and the classification of mazaediate groups of formerly unclear relationship. Cladistics 29:296-308

Rambaut A, Drummond AJ (2007) Tracer v1.4. http://beast.bio.ed.ac. uk/Tracer

Rambold G, Triebel D, Hertel H (1993) Icmadophilaceae, a new family in the Leotiales. In: Feige GB, Lumbsch HT (eds) Phytochemistry and chemotaxonomy of lichenized ascomycetes-a festschrift in honour of Siegfried Huneck. Stuttgart, Berlin

Rehner S, Samuels GJ (1994) Taxonomy and phylogeny of Gliocladium analyzed from nuclear large subunits ribosomal DNA sequences. Mycol Res 98:625-634

Reynolds ES (1963) The use of lead citrate at high $\mathrm{pH}$ as an electron opaque stain in electron microscopy. J Cell Biol 17:208-212

Rodríguez F, Oliver JF, Marin A, Medina JR (1990) The general stochastic model of nucleotide substitution. J Theor Biol 142:485-501

Ronquist F, Teslenko M, van der Mark P, Ayres D, Darling A, Höhna S, Larget B, Liu L, Suchard MA, Huelsenbeck JP (2011) MrBayes 3.2: efficient Bayesian phylogenetic inference and model choice across a large model space. Syst Biol 61:539-542
Rudi K, Skulberg OM, Jakobsen KS (1998) Evolution of cyanobacteria by exchange of genetic material among phyletically related strains. J Bacteriol 180:3453-3461

Schiman-Czeika H (1987) Observation on species of Lempholemma from the East-Alps (Austria). Plant Syst Evol 158:283-288

Schmitt I, Mueller G, Lumbsch HT (2005) Ascoma morphology is homoplaseous and phylogenetically misleading in some pyrenocarpous lichens. Mycologia 97:362-374

Schmitt I, Crespo A, Divakar PK, Fankhauser JD, Herman-Sackett E, Kalb K, Nelsen MP, Nelson NA, Rivas-Plata E, Shimp AD, Widhelm T, Lumbsch HT (2009) New primers for promising single-copy genes in fungal phylogenetics and systematics. Persoonia 23:35-40

Schoch CL, Sung G-H, López-Giráldez F, Townsend JP, Miadlikowska J, Hofstetter V, Robbertse B, Matheny PB, Kauff F, Wang Z, Gueidan C, Andrie RM, Trippe K, Ciufetti LM, Wynns A, Fraker E, Hodkinson BP, Bonito G, Yahr R, Groenewald JZ, Arzanlou M, de Hoog GS, Crous PW, Hewitt D, Pfister DH, Peterson K, Gryzenhout M, Wingfield MJ, Aptroot A, Suh S-O, Blackwell M, Hillis DM, Griffith GW, Castlebury LA, Rossman AY, Lumbsch HT, Lücking R, Büdel B, Rauhut A, Diederich P, Ertz D, Geiser DM, Hosaka K, Inderbitzin P, Kohlmeyer J, Volkmann-Kohlmeyer B, Mostert L, O'Donnell K, Sipman H, Rogers JD, Shoemaker RA, Sugiyama J, Summerbell RC, Untereiner W, Johnston P, Stenroos S, Zuccaro A, Dyer P, Crittenden P, Cole MS, Hansen K, Trappe JM, Lutzoni F, Spatafora JW (2009a) The Ascomycota tree of life: a phylum wide phylogeny clarifies the origin and evolution of fundamental reproductive and ecological traits. Syst Biol 58:224-239

Schoch CL, Wang Z, Townsend JP, Spatafora JW (2009b) Geoglossomycetes cl. nov., Geoglossales ord. nov. and taxa above class rank in the Ascomycota Tree of Life. Persoonia 22:129-138

Schultz M, Büdel B (2002) Key to the genera of the Lichinaceae. Lichenologist 34:39-62

Schultz M, Arendholz W-R, Büdel B (2001) Origin and evolution of the lichenized Ascomycete order Lichinales: monophyly and systematic relationships inferred from ascus, fruiting body and SSU rDNA evolution. Plant Biol 3:116-123

Spurr AR (1964) A low viscosity epoxy resin embedding medium for electron microscopy. J Ultrastrust Res 26:31-43

Stamatakis A (2014) RAxMLVersion 8: a tool for phylogenetic analysis and post-analysis of large phylogenies. Bioinformatics 30:1312-1313

Stenroos S, Myllys L, Thell A, Hyvönen J (2002) Phylogenetic hypotheses: Cladoniaceae, Stereocaulaceae, Baeomycetaceae, and Icmadophilaceae revisited. Mycol Prog 1:267-282

Stenroos S, Högnabba F, Myllys L, Hyvönen J, Thell A (2006) High sensitivity in symbiotic associations of lichenized ascomycetes and cyanobacteria. Cladistics 22:230-238

Stenroos S, Laukka T, Huhtinen S, Döbbeler P, Myllys L, Syrjänen K, Hyvönen J (2010) Multiple origins of symbioses between ascomycetes and bryophytes suggested by a five-gene phylogeny. Cladistics 26:281-300

Stiller JW, Hall BD (1997) The origin of red algae: implications for plastid evolution. Proc Natl Acad Sci USA 94:4520-4525

Talavera G, Castresana J (2007) Improvement of phylogenies after removing divergent and ambiguously aligned blocks from protein sequence alignments. Syst Biol 56:564-577

Tibell L (1984) A reappraisal of the taxonomy of Caliciales. Nova Hedwig Beih 79:597-713

Toledo Rizzini C (1952) On a new Brazilian hemilichen. Arch Jard Bot Rio de Janeiro 12:138-144

Vilgalys R, Hester M (1990) Rapid genetic identification and mapping of enzymatically amplified ribosomal DNA from several Cryptococcus species. J Bacteriol 172:4238-4246 
Voglmayr H, Fournier J, Jaklitsch WM (2019) Two new classes of Ascomycota: Xylobotryomycetes and Candelariomycetes. Persoonia 42:36-49

Wang Z, Binder M, Schoch CL, Johnston PR, Spatafora JW, Hibbett DS (2006a) Evolution of helotialean fungi (Leotiomycetes, Pezizomycotina): a nuclear rDNA phylogeny. Mol Phylogenet Evol 41:295-312

Wang Z, Johnston PR, Takamatsu S, Spatafora JW, Hibbett DS (2006b) Toward a phylogenetic classification of the Leotiomycetes based on rDNA data. Mycologia 98:1065-1075

Wedin M, Tibell L (1997) Phylogeny and evolution of Caliciaceae, Mycocaliciaceae and Sphinctrinaceae (Ascomycota), with notes on the evolution of the prototunicate ascus. Can $\mathrm{J}$ Bot 75:1236-1242

Wedin M, Wiklund E, Crewe A, Döring H, Ekman S, Nyberg A, Schmitt I, Lumbsch HT (2005) Phylogenetic relationships of Lecanoromycetes (Ascomycota) as revealed by analyses of $\mathrm{mtSSU}$ and nLSU rDNA sequence data. Mycol Res 109:159-172
White TJ, Bruns T, Lee S, Taylor JW (1990) Amplification and direct sequencing of fungal ribosomal RNA genes for phylogenetics. In: Innis MA, Gelfand DH, Sninsky JJ, White TJ (eds) PCR protocols: a guide to methods and applications. Academic Press, San Diego, pp 315-322

Wilgenbusch JC, Warren DL, Swofford DL (2004) AWTY: a system for graphical exploration of MCMC convergence in Bayesian phylogenetic inference. http://ceb.csit.fsu.edu/awty

Zhang N, Wang Z (2015) Pezizomycotina: Sordariomycetes and Leotiomycetes. In: McLaughlin DJ, Spatafora JW (eds) The Mycota. Part B, Systematics and Evolution. Springer, Berlin, pp 57-88

Zharkikh A (1994) Estimation of evolutionary distances between nucleotide sequences. J Mol Evol 39:315-329

Zoller S, Scheidegger C, Sperisen C (1999) PCR primers for the amplification of mitochondrial small subunit ribosomal DNA of lichen forming ascomycetes. Lichenologist 31:511-516 